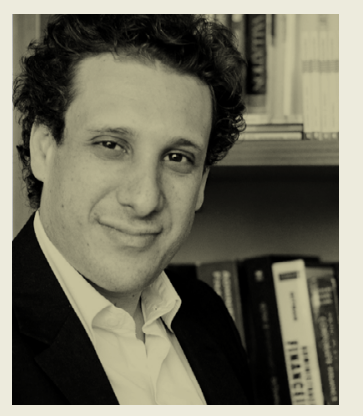

\title{
DECISÕES IMPORTANTES PRECISAM DE UM CÉREBRO DESCANSADO
}

Pense em um dia de trabalho em que você tem grandes decisões a tomar. Apresentação para o chefe, mesa de negociação com clientes grandes, primeiro dia de trabalho depois de uma mudança de posição importante... Esses são alguns exemplos de situações capazes de causar nervosismo em qualquer pessoa.

Em dias assim, as recomendações são: uma boa noite de sono e um café da manhã reforçado antes de começar a jornada de trabalho. Essas dicas, no entanto, não se limitam somente ao bem-estar. Nosso cérebro tende a tomar decisões piores $\mathrm{e}$ mais impulsivas quando está esgotado. Em poucas palavras, nossa capacidade de autocontrole é prejudicada quando o cérebro está cansado.

Essa constatação não surge somente da observação leiga ou do senso comum. Um estudo feito por Shai Danziger, Jonathan Levav e Liora Avnaim-Pesso, pesquisadores de universidades de Israel e dos Estados Unidos, mostrou a mudança de comportamento de juízes na hora de tomar decisões em situações de esgotamento mental. Segundo a pesquisa, o comportamento padrão dos juízes era não conceder liberdade condicional. No entanto, nos períodos do dia em que estavam descansados ou bem alimentados - início da manhã e logo após o almoço tendiam a conceder liberdade condicional com mais facilidade. A decisão que não era padrão - conceder a liberdade - exigia mais esforço. Portanto, ocorria mais facilmente em períodos nos quais o cérebro estava mais apto a sair da zona de conforto.

Esse mesmo resultado pode ser considerado em um ambiente corporativo. Imagine que você reserve o horário em que está mais desgastado para olhar um relatório importante. Seria uma péssima escolha, porque haveria muito mais chances de deixar escapar informações importantes. As tarefas que demandam mais concentração devem ser realizadas nos momentos em que seu cérebro estiver descansado.

No mesmo sentido, o psicólogo econômico Dan Ariely, autor do livro A mais pura verdade sobre a desonestidade, cita um intrigante estudo feito na Universidade de Connecticut, nos Estados Unidos, fazendo correlação entre morte de parentes (geralmente avós) e datas de provas importantes. De um jeito bem irônico, ele aponta que a probabilidade de ocorrer a morte dos avós dos alunos às vésperas das provas semestrais aumenta dez vezes. Às vésperas dos exames finais, a chance fica 19 vezes maior.

Além disso, ele mostra como as atitudes dos alunos se padronizam ao buscar desculpas em períodos nos quais sabem que o cérebro ficará sobrecarregado. De modo geral, ao perceber a iminência do prazo apertado, eles procuram ampliar o tempo de tolerância para a realização das provas como forma de compensar a procrastinação anterior e evitar que o cérebro fique cansado com pouco tempo de estudo.

No ambiente de trabalho, a lógica não é diferente. Em dias de decisões importantes, seu cérebro precisa das melhores condições possíveis para que faça o melhor julgamento diante de uma oportunidade. Com base nisso, avalie sua rotina e a forma como cuida do seu descanso e da sua alimentação com um olhar mais crítico. Seus cuidados podem lhe trazer retornos muito mais relevantes do que simplesmente bem-estar. 